\title{
研究論文
}

放射光発生用挿入光源へのバルク超伝導体の応用

紀井 俊輝 ${ }^{*}{ }^{\dagger}$, 金城 良太 ${ }^{*}$

\section{Application of Bulk High-temperature Superconductor to Insertion Device for Synchrotron Radiation}

\author{
Toshiteru $\mathrm{KII}^{*}, \dagger$ and Ryota KINJO*
}

\begin{abstract}
Synopsis: In this study, we propose a new undulator structure based on a bulk high-temperature superconductor stacked array for insertion devices in synchrotron radiation facilities and free-electron laser devices. A strong periodic magnetic field can be generated in a short period from induced currents in the stacked bulk high-temperature superconductors. This study describes the principle of operation and features of the undulator, and shows the results of generation and control of the periodic magnetic field. We have also developed a numerical model for estimating the performance of the undulator. Excellent performance is expected at approximately $20 \mathrm{~K}$.
\end{abstract}

Key words: bulk superconductor, insertion device, periodic magnetic field, synchrotron radiation, free-electron laser

\section{1. はじめに}

放射光は、相対論的な速度で運動している高エネルギー の荷電粒子が加速度を受け偏向されたときに軌道の接線方 向に放射される電磁波である。電子シンクロトロンの偏向 電磁石から放射される真空紫外光を用いた分光実験が 1963 年にアメリカ国立標準局（National Bureau of

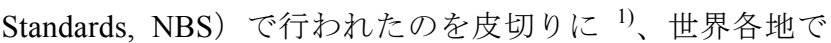
自然科学の広範な分野の基礎および応用研究で放射光が利 用され現在に至っている。加速器の大型化による電子エネ ルギーの増大、専用設計加速器による電子ビームエミッタ ンスの低減、精密な周期交替磁場を生成するアンジュレー タまたはウィグラーと呼ばれる挿入光源の開発により、日 本の SPring-8、米国の APS、欧州の ESRF といった第三 世代放射光施設で、特に、真空紫外から $X$ 線領域で輝度 の高い放射光の発生が可能になり、放射光利用研究が活発 に行われている。第四世代の放射光施設では、特に $\mathrm{X}$ 線 領域において第三世代放射光施設での輝度を数桁上回るき わめて強力な放射光を発生させ、研究可能な対象を広げる ことが計画されており、そのために、電子ビームエミッタ ンスのさらなる低減化や、挿入光源の高度化について研究 が行われている。 $\mathrm{X}$ 線領域のコヒーレント光は次世代の分

Received November 30, 2010

*京都大学 エネルギー理工学研究所

干611-0011 京都府宇治市五ヶ庄

Institute of Advanced Energy, Kyoto University,

Gokasyo, Uji, Kyoto 611-0011, Japan

† E-mail: kii@iae.kyoto-u.ac.jp
子構造解析におけるキーテクノロジーとして特に期待が大 きく、第四世代放射光施設の多くで硬 $X$ 線領域のコヒー レントな放射光の発生を目標とし、周期 $20 \mathrm{~mm}$ 以下の短 周期・強磁場のアンジュレータの採用を計画している。ま た、短周期・強磁場のアンジュレータは既存の放射光施設 においても、より短波長側への波長域拡大が可能になるた め、さらなる強磁場・短周期化の実現を目指した研究が数 多く行われている。

超伝導技術は、より強力な磁場を発生し放射光の輝度を 向上させるために、超伝導線材を用いた偏向電磁石や挿入 光源として実用化に貢献している。さらに、近年、アン ジュレータの強磁場・短周期化を目指した研究として高温 超伝導バルク磁石 (Bulk HTSC Magnet: Bulk High-Tc Superconductor Magnet) の利用も提案されている。高温超 伝導バルク磁石では、これまでに $29 \mathrm{~K}$ で $17 \mathrm{~T}$ の磁場が報 告されており 2)、永久磁石より強力な磁場の発生という観 点からは有望であるが、アンジュレータのような周期的な 磁場生成に応用するためには着磁の問題を解決することが 不可欠である。SPring-8 の Tanaka らはリング状のバルク 超伝導体と永久磁石を組み合わせたクライオアンジュレー タプラス $(\mathrm{CU}+)$ と呼ばれる構造 ${ }^{3)}$ および、直方体状の HTSC を並べこれらを外部磁場により着磁することによ り周期的磁場を発生するピュア型超伝導永久磁石アンジュ レータ (SCPMU) と呼ばれる構造 ${ }^{4)}$ を提案している。ま た、京都大学エネルギー理工学研究所では、ソレノイド中 に周期的に HTSC を配置しソレノイドによる磁場制御に より周期交替磁場を制御するバルク高温超伝導スタガード 
アレイアンジュレータ（Bulk HTSC SAU）と呼ぶ構造を提 案している 5)。この方式は、駆動機構を用いることなく単 一のソレノイドで着磁および制御が可能である、除熱が容 易な構造である、コールドマスが小さい、個々のバルク超 伝導体間の臨界電流密度のばらつきによる影響が低減され る、といった特徵を持つ。本報告では、Bulk HTSC SAU の概念と周期磁場生成・制御実験の結果を示し、挿入光源 としての可能性について議論を行う。

\section{Bulk HTSC SAU}

\section{1 アンジュレータの原理}

本節では、アンジュレータの原理と短周期・強磁場化の 必要性について簡単に説明する。アンジュレータまたは ウィグラーとは、光速に近い速度で通過する電子ビームを 周期的に $\mathrm{N}$ 極と $\mathrm{S}$ 極が交替する磁場によって蛇行させ、 シンクロトロン放射光を発生させる装置である。その模式 図を Fig. 1 に示す。一般に電子ビームの蛇行が大きいもの をウィグラーと呼び小さな物をアンジュレータと呼ぶが、 後述する $K$ 值により分類されることが多い。アンジュ レータで発生するシンクロトロン放射光を特にアンジュ レータ放射光と呼び、その固有の波長 $\lambda_{\mathrm{R}}$ は次の式であら わされる。

$$
\begin{aligned}
& \lambda_{\mathrm{R}}[\AA \mathrm{\textrm {A }}]=\frac{\lambda_{\mathrm{u}}}{2 \gamma^{2}}\left(1+\frac{K^{2}}{2}\right) \approx 13.056 \frac{\lambda_{\mathrm{u}}[\mathrm{cm}]}{(E[\mathrm{GeV}])^{2}}\left(1+\frac{K^{2}}{2}\right) \\
& K=\frac{e \cdot B_{0} \cdot \lambda_{\mathrm{u}}}{2 \pi \cdot m_{0} c} \approx 93.36 B_{0}[\mathrm{~T}] \cdot \lambda_{\mathrm{u}}[\mathrm{m}]
\end{aligned}
$$

ここで、 $\lambda_{\mathrm{u}}$ はアンジュレータの周期、 $\gamma$ は電子ビーム のローレンツ係数、 $E$ は電子ビームエネルギー、 $K$ は磁 場の強さを表現するアンジュレータパラメータ、e は電子 の電荷、 $m_{0}$ は電子の質量、 $c$ は光速、 $B_{0}$ はアンジュレー 夕磁場の振幅である。 $K$ 值が 1 近傍のものをアンジュレー 夕、 $K>>1$ のものをウィグラーと呼ぶ。 $K$ 值が 1 近傍のア

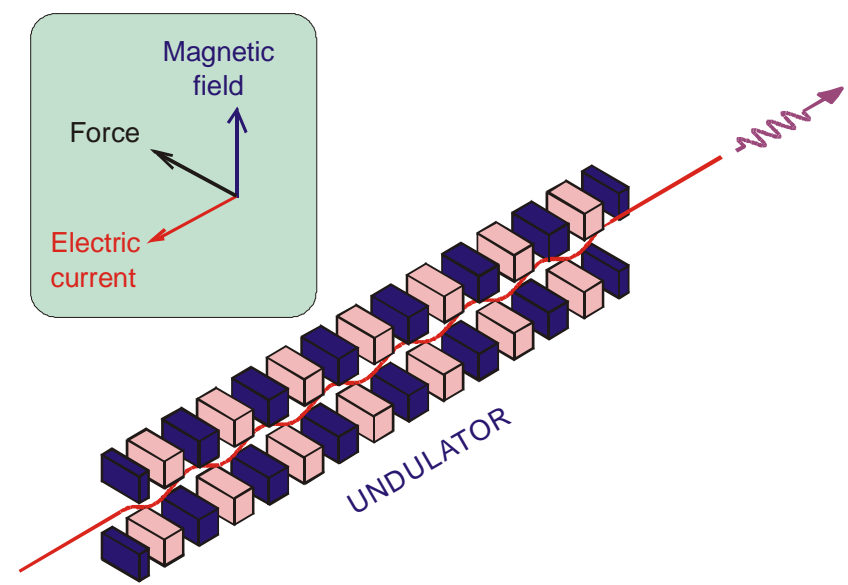

Fig. 1 Principle of undulator radiation. Undulator radiation is generated using a periodic magnetic field.
ンジュレータからは準単色の放射光が発生するが、 $K$ 值の 大きなウィグラーからは高次の高調波がほぼ連続的に生成 され、得られる放射光は白色光となる。当然のことながら、 $\mathrm{X}$ 線領域のコヒーレント光の発生には、アンジュレータが 必要である。第三世代放射光施設においては、高次高調波 による短波長 X 線が必要な場合を除いては、単色性の高 い放射光の発生が可能なアンジュレータが主に用いられて いる。式(1)、(2)からわかるように、短波長の放射光を得 るためには、電子ビームエネルギーを上げることおよび、 アンジュレータの周期を小さくすることが有効である。ま た、 $K$ 值を小さくすることによっても波長は短くなるが、 放射光の強度は磁場の 2 乗に比例するため、強力な放射光 発生には磁場強度を下げ $K$ 值を小さくするという手法は 適していない。そのため、 $K$ 值は単色性を損なわない範囲 で大きくすることが一般的であり、 $K$ 值は $1 \sim 1.5$ 程度と する。このような観点から、次世代放射光で要求されるア ンジュレータとしては短周期化と同時に、強磁場化も要求 されている。式(2)から $K=1.0$ を周期 $10 \mathrm{~mm}$ で実現するた めに必要な磁場強度はおよそ $1.0 \mathrm{~T}$ 、また周期 $5 \mathrm{~mm}$ の場 合には $2.0 \mathrm{~T}$ となり、永久磁石よりも強力な磁場生成が可 能な超伝導技術が重要となる。

\section{2 構造}

本節では、京大グループで提案した Bulk HTSC SAU の 構造について説明する。Bulk HTSC SAU における磁場生 成の概念図を Fig. 2 に示す。電子ビームの軌道を挟み、 図のようにバルク超伝導体を電子ビーム軌道の上下に互い 違いに配置する。これをスタガードアレイ（Staggered Array）構造と呼ぶ。このアレイ構造は、強磁性体を同様

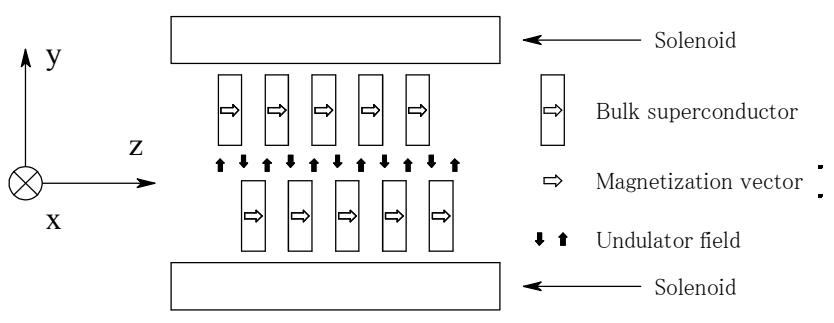

Fig. 2 Schematic side view of the Bulk HTSC SAU.

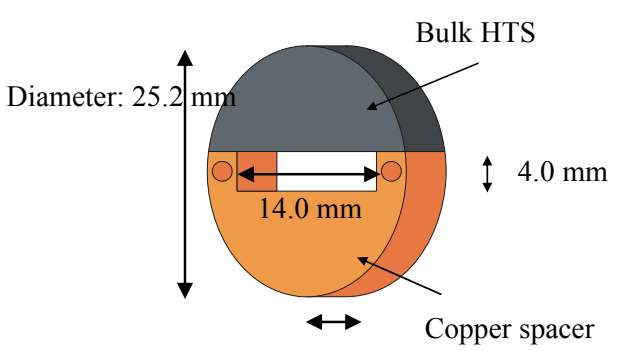

Thickness $2.5 \mathrm{~mm}$

Fig. 3 Half period of the stacked array. 


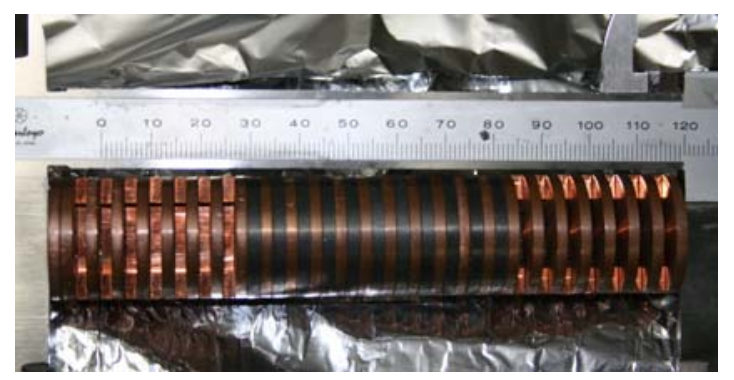

Fig. 4 Photograph of 11 periods of the stacked bulk HTSCs.

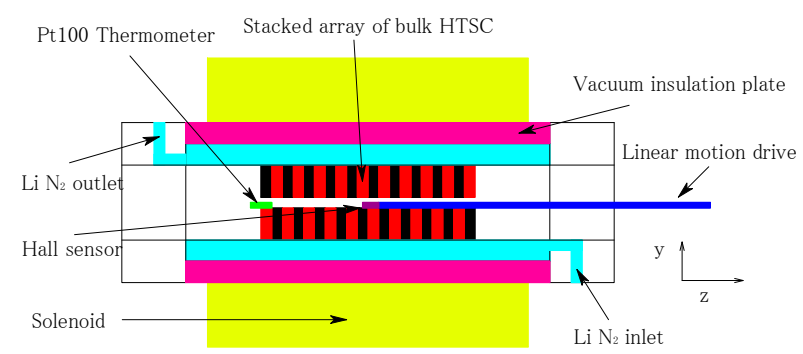

Fig. 5 Schematic side view of the prototype of the Bulk HTSC SAU.

に並ベ、ソレノイドによる $\mathrm{z}$ 方向の磁場を偏向し $\mathrm{y}$ 方向 成分を作り出すスタガードアレイアンジュレータ

(Staggered Array Undulator) ${ }^{6)}$ で採用されたものである。

試験機の構造を以下に示す。Fig. 3 に示すように準半円 形のバルク超伝導体とそれを保持し、かつ伝導冷却の機能 を併せ持つ銅スペーサを基本ユニットとする。これを上下 交互にスタックしたアレイユニットを、中間層に液体窒素 を導入可能な 2 重真空ダクトに挿入し、ダクト外壁を真空 断熱パネルで覆いソレノイドの中心軸上に設置して動作さ せる。磁場計測は低温で使用可能なホール素子を直線導入 器の先端に取り付けた樹脂プレート上に固定し、ソレノイ ド中心軸上を操作することにより行う。また、アレイユ ニットの温度は銅スペーサに張り付けたフィルム状の白金 抵抗測温体を用いてモニターする。Fig. 4 にアレイユニッ トの写真、Fig. 5 に試験機の模式図を示す。

\section{3 動作原理}

本節では Bulk HTSC SAU の動作原理について説明を行 う。Bulk HTSC SAU では、個々のバルク超伝導体内部に 誘起される誘導電流により電子ビーム軌道上に周期的磁場 を作り出す。動作原理の説明に際し、臨界電流密度が磁場 に依存しない単純な Bean モデルを仮定する。したがって、 冷却前にあらかじめ磁場を印加する磁場中冷却であるか、 ゼロ磁場冷却であるかは問わない。バルク超伝導体を超伝 導転移温度以下に冷却したのち、ソレノイドにより磁場を 変化させる。その結果、磁場変化を打ち消すようにバルク 超伝導体の内部に誘導電流が発生する。個々のバルク超伝 導体に誘導される電流は、他のバルク超伝導体の作る磁場 も重ね合わせの原理により影響を与えるため、打ち消され

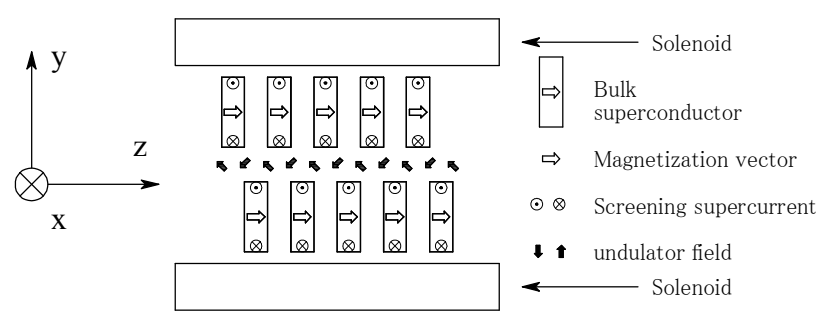

Fig. 6 Generation principle of the periodic undulator field using a screening current.

る磁場変化はソレノイドにより与えられる磁場変化とバル ク超伝導体の作る磁場の合成磁場に相当する。このとき、 誘導電流は個々のバルク超伝導体の外縁部から現れる。こ の過程は、個々の準半円型の超伝導ループコイルが永久電 流モードで励磁されたみなすことができる。この電流によ りソレノイドコイルの中心軸上、すなわち電子ビーム軌道 上に周期交替磁場が生成される。Fig. 2 に示した Bulk HTSC SAU の動作原理の模式図をループ状の誘導電流を 用いて表現し、アンジュレータ磁場が生成されている様子 を示した模式図を Fig. 6 に示す。Fig. 6 では、初期状態と してソレノイドにより $+\mathrm{z}$ 方向に磁場を与え、終状態とし てソレノイドの励磁を行っていない状態を示している。

Fig. 6 に示すように、ループ電流がソレノイドの中心軸上 に生成する磁場には-Z 方向の磁場成分が含まれるため、 土y 方向のアンジュレータ磁場のほか、 $-\mathrm{z}$ 方向の磁場がア ンジュレータ内に生成されている。 $-\mathrm{z}$ 方向の磁場成分に ついては終状態においてソレノイドの作る磁場を残すこと で補償可能である。またソレノイドが与える磁場変化量を 制御することで、周期交替磁場の強度が制御可能である。

このように、Bulk HTSC SAU はバルク超伝導体を用いた アンジュレータでありながら、その磁場生成機構は巻線型 の超伝導電磁石アンジュレータと類似している。バルク超 伝導体を擬似的なコイルとみなし周期交替磁場の生成が可 能になったのは、組織内での一様性が高く、またロット間 でのばらつきの比較的小さな単一ドメインのバルク超伝導 体の製造が可能になってきたことによるところが大きい。

\section{4 特徵}

前節で示したように、単一のソレノイドを用い、駆動機 構を用いることなく周期磁場生成および磁場制御が可能で あることが Bulk HTSC SAU の最も重要な特徵となってい る。放射光発生用の挿入光源として実用的な性能を達成す るには、短周期・強磁場の生成のみではなく、精度や安定 性も重要な要件である。

放射光発生装置に固有の問題としては、放射光による発 熱および電子ビームが磁石近傍を通過する際の誘導電流に よる発熱があげられる。そのため、永久磁石を用いたアン ジュレータにおいては磁石の冷却が重要とされ、特にネオ ジム系磁石の場合には温度の上昇とともに保持力が低下寸 
るため注意が必要である。バルク超伝導体の場合において も、温度の上昇は臨界電流密度の低下につながり、冷却性 能は極めて重要である。除熱の観点からは、Bulk HTSC SAU では基本ユニットを上下交互に積層する構造である ため、それぞれのバルク超伝導体が高い熱伝導率の銅ス ペーサに大面積で接触しており高い冷却性能の実現が容易 な構造となっている。また、駆動機構を持たないため、室 温部分との接触がなく、また冷却を要するコールドマスも 必要最低限で良い。特に、ギャップ間隔が短い真空封止型 アンジュレータでは、誘導電流による発熱が主な熱源と なっており、1 m あたり $10 \mathrm{~W}$ 程度が永久磁石表面にコー トした銅表面で発生するが 7)、Bulk HTSC SAU の実用機 は、 $20 \mathrm{~K}$ 程度で運用されることが想定されており、銅の 比抵抗の低下に伴い発熱が $1 / 10$ 以下となるため、発熱の 影響を小さくすることができる。

一般にアンジュレータで必要とされるピーク磁場のばら つきは $1 \%$ 以下であるが、磁場の均一度を左右する臨界電 流密度のばらつきは、永久磁石の磁化のばらつきに比べ大 きく、1\%程度のばらつきのバルク超伝導体の入手は現時 点では困難を伴う。ところが、Bulk HTSC SAU は、各バ ルク超伝導体の外周部のおよそ $10 \sim 20 \%$ の領域のみに誘 導電流が流れる条件で動作させるため、バルク超伝導体中 心部の磁束密度は、臨界電流密度のばらつきが存在しても 誘導電流の流れる領域が自動的に変化することにより一定 に保たれる。これに伴い、誘導電流により生成されるアン ジュレータ磁場も同様に補償されるが、誘導電流の流れる 領域が変化する影響があるため、完全な補償は行われない。 この効果を数值計算により評価したところ、アンジュレー 夕磁場のばらつきは、臨界電流密度のばらつきの $1 / 7 \sim 1 / 5$ 程度にまで圧縮され、超伝導材料に対する要求レベルが緩 和されている ${ }^{8)}$ 。この効果は誘導電流の流れる領域が変化 する場合にのみ有効であるので、超伝導体全体に誘導電流 が流れる飽和状態においては、臨界電流密度のばらつきが そのままアンジュレータ磁場のばらつきとなる。また、ば らつきに関しては、臨界電流密度を指標に隣接するバルク 超伝導体間の臨界電流密度の差が小さくなるようにバルク 超伝導体の配列順をソート寸ることで周期磁場の位相・振 幅誤差を低減させることも可能である。この手法は永久磁

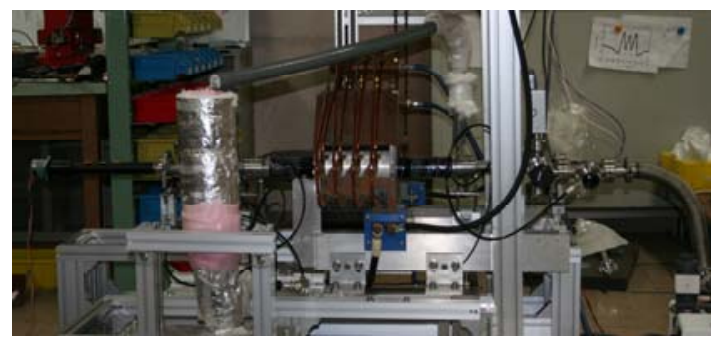

Fig. 7 Photograph of the second prototype of the Bulk HTSC SAU.
石型アンジュレータにおいて、磁石ソーティング法として すでに確立しており、Bulk HTSC SAU への適用が可能で ある。また、バルク超伝導体が損傷した場合には、室温に 戻せば特別な治具を用いることなく取り外しが可能である。 さらに、機械加工により誘導電流の流れる領域の位置およ び形状を変化させることが可能であり、磁場の均一度の向 上や、アンジュレータの両端での磁場分布の制御が可能で ある。

\section{3. 実験手法}

\section{1 実験装置}

Fig. 7 に実験に用いたプロトタイプ 2 号機の写真を示す。 ボア径 $76 \mathrm{~mm}$ のソレノイドコイルの中心軸上には、バル ク超伝導体で冷却可能な 2 重真空ダクトが設置されている。 実験に用いたバルク超伝導体は $\mathrm{QMG}$ 法を用いて製作され た新日本製鐵製の $\mathrm{REBaCuO}$ バルク超伝導体 ${ }^{9)}$ で、初期の 実験では Dy 系、後期の実験では Gd 系を利用した。実験 で用いたバルク超伝導体の $77 \mathrm{~K}$ における臨界電流密度は $100 \sim 400 \mathrm{~A} / \mathrm{mm}^{2}$ である。Fig. 3 に示したように、バルク超 伝導体の形状は直径 $25.2 \mathrm{~mm}$ の円盤から切り出した準半 円形で、厚みは $2.5 \mathrm{~mm}$ のものを用いた。このとき、対向 するバルク超伝導体列間の間隔（ギャップ）は $4.0 \mathrm{~mm}$ と なっている。超伝導体の $\mathrm{c}$ 軸はソレノイド軸（ $\mathrm{z}$ 軸）と平 行になるように切り出しを行っている。2 重冷却ダクトは、 バルク超伝導体が接触する部分はアルミニウム合金とし、 ステンレス製フランジを両端に接合してある。内側をアル ミニウム合金としたことで、室温で超伝導体アレイを挿入 したのち冷却することで、収縮により熱接触を高めること が可能になっている。2 重冷却ダクトの外側には真空排気 可能な樹脂製チューブを巻き、さらに真空断熱パネルを巻 くことで大気側からの熱入力を遮断している。また、直線

Table 1 Specifications of the Bulk HTSC SAU

\begin{tabular}{c|l}
\hline \hline \multirow{2}{*}{ Gauss meter } & $\begin{array}{l}\text { Model : Lake Shore Model } 460 \\
\text { 3-channnel gauss meter }\end{array}$ \\
\hline \multirow{3}{*}{ Hall sensor (y) } & $\begin{array}{l}\text { Model: Lake Shore HGCT-3020 } \\
\text { Temperature range: } 4.2-375 \mathrm{~K} \\
\text { Thermal coefficient of } \mathrm{V}_{\text {Hall }} \text { - } 0.01 \% / \mathrm{K} \\
\text { Effective area: } 1.02 \mathrm{~mm} \text { in diameter }\end{array}$ \\
\hline \multirow{3}{*}{ Hall sensor (z) } & $\begin{array}{l}\text { Model : Lake Shore XMFCA-1498 } \\
\text { Temperature range: }>77 \mathrm{~K}\end{array}$ \\
& $\begin{array}{l}\text { Hall voltage @ } 77 \mathrm{~K}: 121 \% \text { of room } \\
\text { temp. } \\
\text { Effective area: 0.127 mm } \times 0.127 \mathrm{~mm}\end{array}$ \\
\hline \multirow{3}{*}{ Solenoid } & $\begin{array}{l}\text { Type: Normal conducting } \\
\text { Bore diameter: 76 mm } \\
\text { Total length: } 400 \mathrm{~mm} \\
\text { Magnetic field @ } 200 \mathrm{~A}: 0.273 \mathrm{~T}\end{array}$ \\
\hline Temperature & $\begin{array}{l}\text { Type: Pt100 thin-film platinum resistance } \\
\text { thermometer }\end{array}$ \\
\hline \hline
\end{tabular}




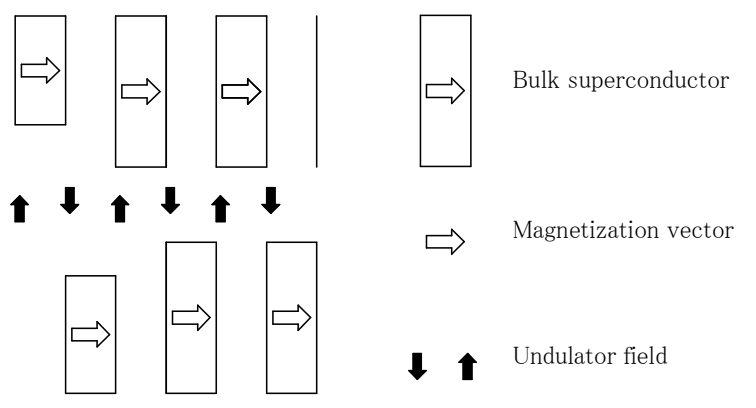

Fig. 8 Arrangement of the bulk HTSC for end field termination.

導入器による熱入力を低減させるため、ホール素子は厚さ $1.0 \mathrm{~mm}$ のテフロン製の薄板に固定し、自重でアレイユ ニットの内側の空間に接触する構造とした。実験装置の主 要諸元を Table 1 に示す。

\section{2 周期磁場生成・制御試験}

磁場生成・制御試験はゼロ磁場冷却法により行った。実 験には $\mathrm{DyBaCuO}$ バルク超伝導体を用いた。出荷時検査で 液体窒素温度での最大捕捉磁場分布の計測が行われたが、 中心部のピーク磁束密度は $0.08 \sim 0.14 \mathrm{~T}$ に分布していた。 バルク超伝導体内部の誘導電流が流れる領域とアンジュ レータ磁場分布の関係を評価するため、冷却後の $\mathrm{z}$ 方向磁 場は $0 \sim 0.27 \mathrm{~T}$ の範囲で変化させた。実験に用いたバルク 超伝導体の性能のばらつきが大きいが、製造ロットが異な るものを実験に用いたことと、臨界電流密度に非対称性が ある円柱状の試料から超伝導体が切り出されたことが原因 であると考えられる。

\section{3 端部磁場補正試験}

永久磁石型アンジュレータでは、両端部の磁石サイズを 同一にした場合、磁場振幅が 2 倍になるため、磁石サイズ を半分にすることで両端部での磁場を補正している。とこ ろが、Balk HTSC SAU では端部のバルク超伝導体の厚さ を半分にしても、誘導電流の流れる領域が自動的にバルク 超伝導体の中心部に向かい増大し、厚さの制御では磁場補 正ができないことが予測される。そこで、機械加工によっ てソレノイド中心軸上からの距離が遠くなる端部用のバル ク超伝導体を製作し、端部磁場補正試験を行った。端部磁 場補正に用いたバルク超伝導体配置図を Fig. 8 に示寸。 なお、端部磁場補正実験には $\mathrm{GdBaCuO}$ バルク超伝導体を 用いた。

\section{4. 結果と考察}

\section{1 周期磁場生成・制御}

Fig. 9 に $\mathrm{z}$ 方向磁場変化がバルク超伝導体全体に臨界電 流が誘起される磁場変化より十分小さい場合の磁場生成・ 制御の結果を示す。バルク超伝導体を流れる誘導電流によ りソレノイドの中心軸上に周期交替磁場が生成され、また

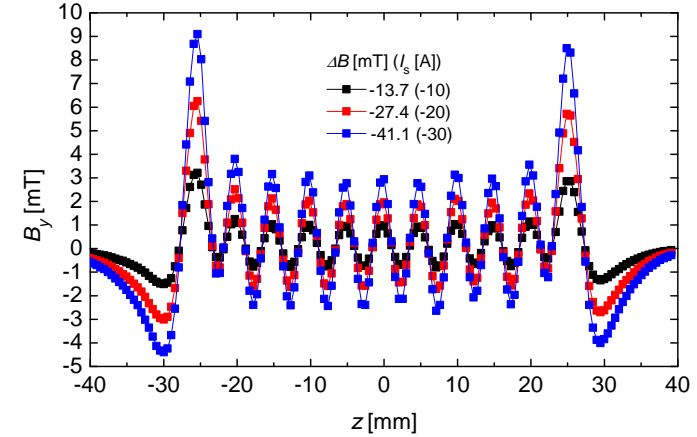

Fig. 9 Field distribution on the central axis of the solenoid at low field ( $\triangle B<<$ Saturated field).

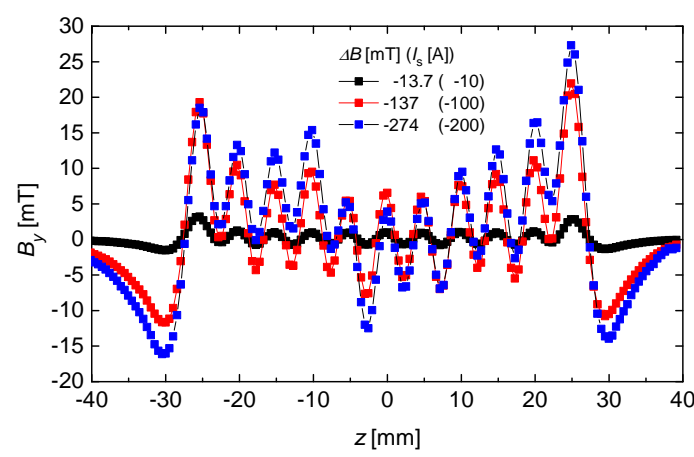

Fig. 10 Field distribution on the central axis of the solenoid at high field ( $\Delta B \cong$ Saturated field).

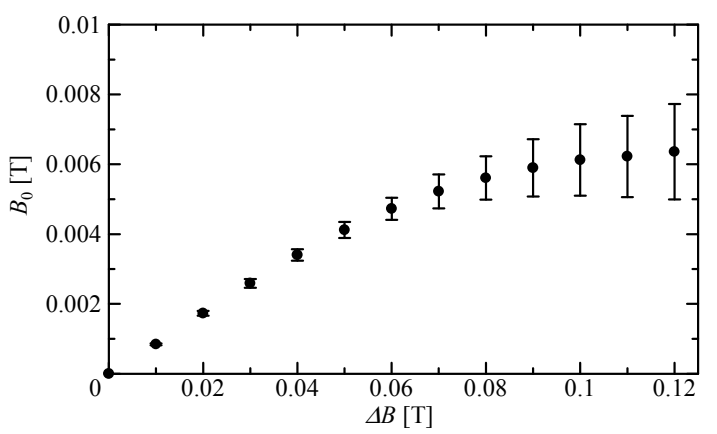

Fig. 11 Average transverse magnetic field of the six central peaks. The error bar indicates standard deviation among the six peaks.

$\mathrm{z}$ 方向磁場の変化量に比例して磁場振幅が強くなることが 確認できた。アンジュレータ磁場の強度は与えた $\mathrm{z}$ 方向の 磁場変化のおよそ $1 / 10$ であった。この值は、バルク超伝 導体の形状や周期とギャップの比率等の幾何学的条件で決 まる值である。また Fig. 10 に z 方向磁場変化が一部もし くはすべてのバルク超伝導体の全体に誘導電流が流れる磁 場変化を超える場合の磁場生成の結果を示す。飽和後は ピーク磁場の強度が部分的にしか増大していないほか、y 方向磁場のピーク強度のばらつきが非常に大きくなってい 


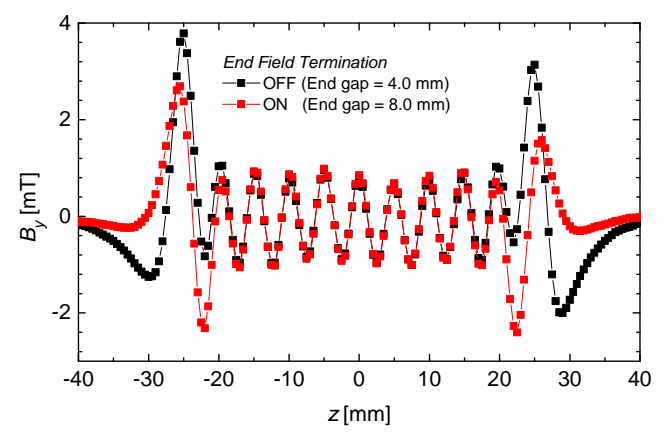

Fig. 12 Effect of the end field termination.

ることがわかる。Fig. 11 に中心部の 6 つのピークの磁場 強度および標準偏差を示す。ソレノイドの与える磁場変化

$(\Delta B)$ が誘導電流の飽和より十分に小さな領域では、ア ンジュレータ磁場は $\Delta B$ に比例しているとともに、ピーク 間のばらつきも飽和磁束密度のばらつき（15\%）に比べて 小さくなっている。ところが、一部のバルク超伝導体で飽 和が始まる $\Delta B=0.08 \mathrm{~T}$ あたりを境に線型性から大きく外 れるとともに、ピーク間のばらつきが増大していくことが 読み取れる。これらの特性から、冷却によりバルク超伝導 体の臨界電流密度を向上すれば、線形性を示す範囲が飛躍 的に向上することが予想できる。ピーク間のばらつきは、 アンジュレータ磁場が $5 \mathrm{mT}$ までは $2 \sim 5 \%$ であった。 個々の臨界電流密度のばらつきが $15 \%$ 程度であつたこと がアンジュレータで必要とされる $1 \%$ 以下のピーク磁場の ばらつきを達成できなかった原因であると考えられる。磁 場の均一度に関しては、超伝導性能の均一化が不可欠であ る。

\section{2 端部磁場補正}

Fig. 12 に端部のバルク超伝導体の形状を、ソレノイド 中心軸からの距離が $2 \mathrm{~mm}$ から $4 \mathrm{~mm}$ へと 2 倍に増加する ようにし、対向する超伝導体列間のギャップを $4 \mathrm{~mm}$ から $8 \mathrm{~mm}$ 一と変化させた場合の磁場計測結果を示す。最端部 におけるピーク磁場の減少が確認され、機械加工によりバ ルク超伝導体の形状を変化させることにより磁場分布を制 御可能であることが確認できた。ただし、より精密な補正 に関しては、以下に述べる数值モデルによる予測を行い、 最適な形状を明らかにしていく必要がある。

\section{3 等価電流モデル}

全節までに示したように、Bulk HTSC SAU はバルク超 伝導体内部に誘起される誘導電流により周期磁場を生成す るものとして定性的に理解できるが、実機の設計や性能予 測を行うためには、計算モデルの構築が不可欠である。動 作原理検証実験では、液体窒素を冷媒に用いたことから、 アンジュレータ磁場は数 $\mathrm{mT}$ にとどまっており、実機で必 要な $1 \mathrm{~T}$ 以上のアンジュレータ磁場が冷却とバルク超伝導 体の大型化によって生成可能であるのかを調査することが

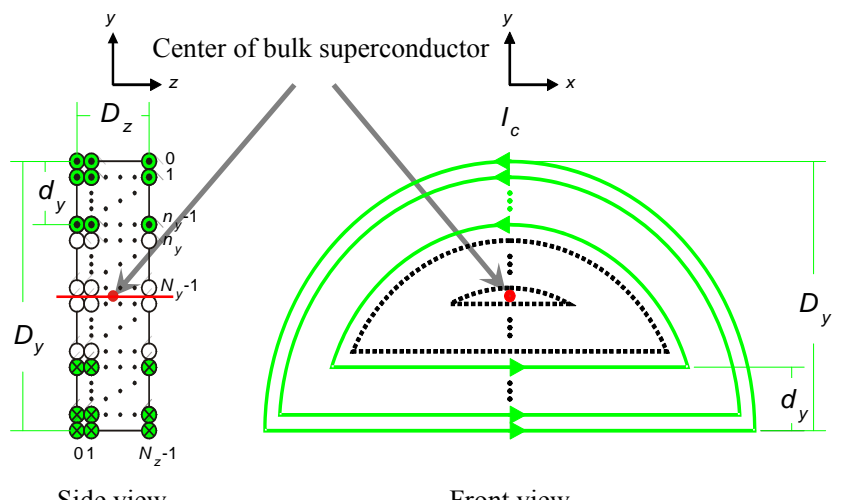

Side view

Front view

Fig. 13 Schematic drawing of the loop current expression for the bulk superconductor. $N_{\mathrm{z}} \times n_{\mathrm{y}}$ loops of supercurrent retain the field strength at the center of the HTSC.

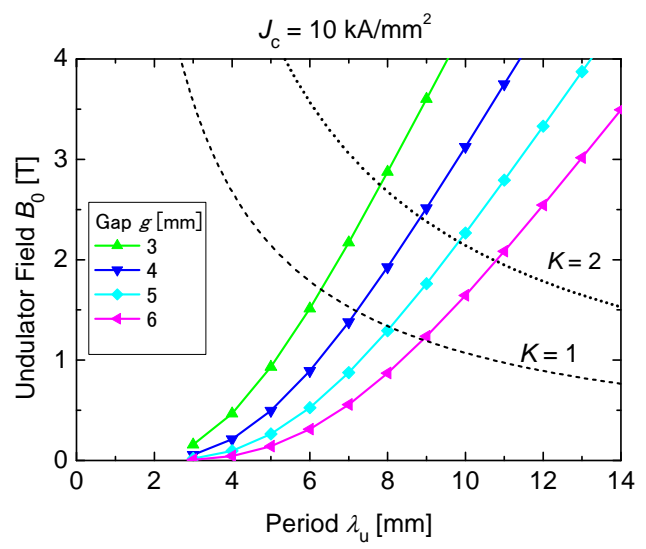

Fig. 14 Expected performance of the Bulk HTSC SAU. The loop current model is used for numerical calculation.

不可欠である。有限要素法等を用いて、計算を行うことは 原理的には可能であるが、性能にばらつきのある多数のバ ルク超伝導体を配置し、それぞれの超伝導体の作る磁場が 互いに影響を及ぼしあう系においては、実用的な計算速度 で設計や最適化研究を進めることには困難が伴う。そこで Bulk HTSC SAU では超伝導体を貫く磁束の強度・向きが ほぼ一様であることに着目し、準半円形のバルク超伝導体 に誘起されるループ状の誘導電流をモデル化した数值計算 コードの開発を行った ${ }^{10)}$ 。このモデルでは、誘導電流は 超伝導体の $\mathrm{ab}$ 平面内のみを流れ、また、その臨界電流密 度は磁場によらず一定とする単純なビーンモデルを仮定し た。Fig. 13 に超伝導体内部の誘導電流のループ電流表現 モデルの模式図を示す。 $D_{\mathrm{y}}$ はバルク超伝導体の高さ、 $D_{\mathrm{z}}$ はバルク超伝導体の厚さ、 $d_{\mathrm{y}}$ は誘導電流が流れる領域の 深さを示す。アンジュレータ磁場は個々のバルク超伝導体 と相似形の $N_{\mathrm{z}} \times n_{\mathrm{y}}$ 本のループ電流のつくる磁場の重叔合 わせで表現した。個々のバルク超伝導体における深さ方向 のループ電流の本数 $n_{\mathrm{y}}$ は、それぞれのバルク超伝導体の 
中央での磁束密度の変化を打ち消すように定めた。他の超 伝導体のループ電流のつくる磁場の影響も考慮する必要が あるため、反復計算を行い $n_{\mathrm{y}}$ を決定する。このような単 純なモデルではあるが、実験で生成された磁場分布および 強度を良く再現することができた。計算手法の詳細につい ては文献 10)を参照されたい。

\section{4 性能予測}

前節に示した数值計算モデルを用いて、直径 $130 \mathrm{~mm} の$ 大型バルク超伝導体から切り出した準半円形バルク超伝導 体を冷却し、臨界電流密度として $10 \mathrm{kA} / \mathrm{mm}^{2}$ を得たとい う仮定に基づき、Bulk HTSC SAU の性能予測を行った。 $10 \mathrm{kA} / \mathrm{mm}^{2}$ の臨界電流密度は $\mathrm{REBaCuO}$ では $10 \sim 30 \mathrm{~K}$ 程 度で得られることが期待できる。Fig. 14 に対向するバル ク超伝導体列間のギャップ $3 \sim 6 \mathrm{~mm}$ の場合の磁場強度と 周期の関係を示す。近年の永久磁石型アンジュレータで用 いられているギャップ 3 6 $\mathrm{mm}$ での性能は、典型的な值 としてギャップ $3 \mathrm{~mm}$ 、周期 $8 \mathrm{~mm}$ のときに磁場強度 $2.8 \mathrm{~T}(\mathrm{~K} \approx 2)$ 、ギャップ $5 \mathrm{~mm}$ 、周期 $8 \mathrm{~mm}$ のときに 磁 場強度 $1.2 \mathrm{~T} （ \mathrm{~K} \approx 1)$ といった性能が予測された。この值 は、現存する永久磁石型アンジュレータ（例：ギャップ $3.2 \mathrm{~mm}$ 周期 $11 \mathrm{~mm}$ のときの磁場強度 $0.7 \mathrm{~T}$ ）を大幅に上 回るものである。

\section{5. 結論}

京都大学エネルギー理工学研究所では次世代の放射光施 設における重要な要素技術の一つである短周期・強磁場ア ンジュレータの候補として、バルク超伝導体内部に誘起さ れる誘導電流を利用した新型アンジュレータを提案してい る。本報告では、短周期・強磁場アンジュレータに関する 研究動向を述べたのち、Bulk HTSC SAU の動作原理及び 特徵について議論を行った。磁場生成・制御実験の結果は バルク超伝導体内部のループ状の誘導電流がアンジュレー 夕磁場を生成するという動作原理を実証した。本原理に基 づく周期磁場生成が可能になったことには、一様性の高い バルク超伝導体の製造が可能なったことが大きく寄与して いる。またバルク超伝導体内部のループ状の誘導電流で表 現する解析モデルを構築し、反復計算を行うことでアン ジュレータ磁場分布を計算する計算モデルの開発を行った。 この計算モデルを用いて、臨界電流密度 $10 \mathrm{kA} / \mathrm{mm}^{2}$ とな る低温環境下で大型バルク超伝導体を用いた場合の性能予 測を行った。その結果、既存の永久磁石型アンジュレータ や超伝導コイル型アンジュレータで到達可能な短周期・強 磁場性能を上回る性能を達成できる高い潜在能力が明らか になった。Bulk HTSC SAU の実用機製作に向けては、20 $\mathrm{K}$ 近傍での動作試験、長時間安定性の確認、数值計算コー ドの高精度化、周期磁場の位相・振幅誤差の補正手法の開 発、バルク超伝導材料の最適化等を継続して行う必要があ
り、開発を継続していく予定である。特に、バルク超伝導 体の特性の向上はアンジュレータ性能の向上に直接つなが るため、今後の材料科学の発展に大きな期待をしている。

バルク超伝導体の製造及び特性計測に関しては、新日本 製鐵株式会社 手嶋英一博士をはじめとする新日本製鐵先 端技術研究所の協力を得た。また、本研究は科学研究費補 助金 基盤研究 B（21340057）および特別研究員奨励費の 補助を受けたことをここに記す。

\section{参 考 文 献}

1) R. P. Madden and K. Codling: "New autoionizing atomic energy levels in $\mathrm{He}, \mathrm{Ne}$, and Ar", PRL 10 (1963) 516-518

2) M. Tomita and M. Murakami: "High-temperature superconductor bulk magnets that can trap magnetic field of over 17 tesla at 29 K", Nature 421 (2003) 517-520

3) T. Tanaka, R. Tsuru, T. Nakajima and H. Kitamura: "Magnetic characterization for cryogenic permanent-magnet undulators: a first result”, J. Synchrotron Rad. 14 (2007) 416-420

4) T. Tanaka, et al.: "Pure type superconducting permanent magnet undulator", J. Synchrotron Rad. 12 (2005) 442-447

5) T. Kii, et al.: "Design study on high- $\mathrm{T}_{\mathrm{c}}$ superconducting microundulator", Proceedings of FEL 2006 (2006) 653-655

6) Y.C. Huang, et al.: "Compact far-IR FEL design", Nucl. Instr. Meth. A 318 (1992) 765-771

7) T. Hara and X.-M. Marechal: "Beam test of the in-vacuum hybrid undulator at ESRF”, SPring-8 利用者情報 1 No. 5 (1996) 17-21

8) T. Kii, et al.: "A study on field error of bulk HTSC staggered array undulator originated from variation of critical current density of bulk HTSCs", Proceedings of FEL 2010 (2010) THPC02

9) M. Morita, H. Teshima and H. Hirano: "Development of oxide superconductors", Nippon Steel Technical Report No. 93 (2006) 18-23

10) R. Kinjo, et al.: "Numerical evaluation of bulk HTSC staggered array undulator by bean model", Proceedings of FEL 2009 (2009) 746-749

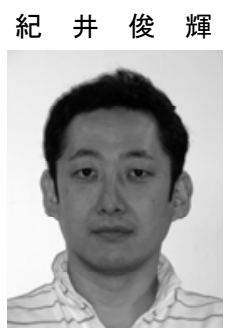

1971 年 8 月 9 日生。1994 年東京工業大学 理学部卒業。1999 年同大学院理工学研究科博 士後期課程（応用物理学専攻）修了。1999 年 京都大学エネルギー理工学研究所に採用（助 手)。赤外自由電子レーザー施設の開発、バル ク超伝導体を用いたアンジュレータの開発に 従事。2008 年からは同研究所・准教授。低温 工学協会, 日本物理学会, 日本原子力学会、 日本加速器学会会員。博士 (理学)。

金 城 良 太 1983 年 7 月生。 2008 年京都大学工学部電 気電子工学科卒業。京都大学大学院エネルギー科学研究科博士後 期課程在学中。日本学術振興会特別研究員 $\mathrm{DC} 1$ 。主にバルク超伝 導アンジュレータの開発に従事。日本原子力学会、日本加速器学 会会員。修士(エネルギー科学)。 